\title{
Pemahaman Konsep Matematis Siswa Kelas VIII pada Materi Lingkaran
}

\author{
Attin Warmi \\ Program Studi Pendidikan Matematika, Universitas Singaperbangsa Karawang \\ Jalan HS. Ronggo Waluyo, Karawang, Jawa Barat, Indonesia \\ warmi.attin@gmail.com
}

Artikel diterima: 10-10-2018, direvisi: 26-05-2019, diterbitkan: 31-05-2019

\begin{abstract}
Abstrak
Banyak siswa yang kesulitan dalam memahami konsep matematika. Tujuan dari penelitian ini untuk mengetahui kemampuan pemahaman konsep siswa dalam menyelesaikan soal-soal pada pokok bahasan Lingkaran. Metode yang digunakan dalam penelitian ini adalah metode deskriptif dengan penelitian kasus. Materi tentang Lingkaran merupakan materi yang terdapat di SMP kelas VIII pada semester genap dan materi ini merupakan salah satu materi yang berhubungan dengan kehidupan sehari hari. Kelas VIII F SMPN 3 Karawang Barat dipilih sebagai subjek penelitian. Pengumpulan data dilakukan dengan pemberian tes tertulis kemampuan pemahaman konsep. Soal berbentuk uraian yang sebelum digunakan sudah di uji validasi. Hasil penelitian ini menunjukan rata-rata nilai kemampuan pemahaman konsep matematis siswa adalah 10,06 termasuk dalam kriteria sedang. Hasil analisis konsep per indikator, diketahui siswa sangat kurang pada indikator menerapkan hubungan antar konsep dan prosedur, kemudian dalam menerapkan konsep secara algoritma. Masih terdapat banyak siswa yang memiliki pemahaman konsep yang kurang.

Kata Kunci: kemampuan pemahaman konsep, metode deskriptif, Lingkaran.
\end{abstract}

\section{Understanding of Mathematical Concepts Class VIII Students in Circle Materials}

\begin{abstract}
Many students have difficulty understanding mathematical concepts. The purpose of this study is to determine the ability to understand students' concepts in solving questions on the subject of the Circle. The method used in this research is descriptive method with case research. The material about Circles is the material found in class VIII SMP in the even semester and this material is one of the materials related to daily life. Class VIII F of SMP 3 Karawang Barat was chosen as the research subject. Data collection is done by giving written tests the ability to understand concepts. Questions in the form of descriptions that have been validated before being used. The results of this study show the average value of the ability to understand students' mathematical concepts is 10.06 which is included in the criteria of being. The results of concept analysis per indicator, it is known that students are very lacking in indicators applying relationships between concepts and procedures, then in applying the concept algorithmically. There are still many students who lack an understanding of concepts. Keywords: conceptual ability, descriptive method, circle.
\end{abstract}




\section{Pendahuluan}

Matematika erat kaitannya dengan geometri dan bilangan yang saling berhubungan diantara keduanya (Sundayana, 2013). Senada dengan hal tersebut Suherman (2001) yaitu: “(a) Kedudukan matematika sebagai induk dari ilmu pengetahuan yang beranggapan bahwa matematika adalah ilmu dasar yang strategis yang wajib dipelajari di setiap tingkatan kelas pada satuan pendidikan baik dasar, menengah maupun tinggi. (b) Tujuan pembelajaran matematika sekolah yaitu melatih siswa untuk selalu berorientasi pada kebenaran dengan mengembangkan sikap logis, kritis, kreatif, objektif, rasional, cermat, disiplin dan mampu bekerja sama dengan efektif". Berdasarkan dua pendapat tersebut tujuan matematika sangatlah penting untuk dapat dimiliki oleh setiap siswa mulai dari berpikir kreatif (Fitriani \& Yarmayani, 2018), analitis sampai dengan berpikir kritis (Alexandra \& Ratu, 2018), dan refleksi diri dengan bertanya (Afriansyah, 2017).

Di samping hasil belajar kemampuan pemahaman konsep menjadi tujuan penting dalam pembelajaran matematika. Pemahaman konsep perlu dimiliki dalam memahami matematika secara menyeluruh (Muna \& Afriansyah, 2016), seperti yang diungkapkan oleh Zulkardi (2003) bahwa mata pelajaran matematika menekankan pada konsep. Berdasarkan pernyataan tersebut artinya bahwa sebelum mempelajari matematika secara lebih lanjut maka konsep-konsep dasar yang terdapat dalam matematika harus benar-benar dikuasai terlebih dahulu, dengan begitu siswa akan lebih mudah dalam menerima materi yang selanjutnya.

National Counsil of Teaching Mathematics (NCTM) memberikan gambaran penting mengenai pentingnya kemampuan pemahaman konsep yaitu: "para peserta didik harus belajar matematika dengan pemahaman, secara aktif membangun pengetahuan baru dari pengalaman dan pengetahuan sebelumnya".

Belajar matematika tidak terbatas mengenai hitungan, disamping itu perlu juga kecakapan matematis setelah belajar matematika. Oleh karena itu pemahaman menjadi pondasi yang sangat penting dalam matematika (Van de Walle, 2006).

Anderson (Ekafitria, 2012) yang mengungkapkan bahwa salah satu bagian dari pemahaman adalah proses interpreting (interpretasi) yang terjadi jika subjek mampu mengkonversi informasi dari satu representasi ke representasi yang lain. Interpretasi meliputi konversi katakata ke dalam kata-kata, gambar ke dalam kata-kata, dan sebagainya. Dalam tahap memahami masalah, subjek berkemampuan penalaran tinggi (ST), subjek berkemampuan penalaran sedang (SS) dan subjek berkemampuan penalaran rendah (SR) memiliki jenis pemahaman yang sama yaitu pemahaman formal yang ditandai dengan indikator mampu menuliskan kembali apa yang ditanyakan dan diketahui dari soal dengan Mosharafa: Jumal Pendidikan Matematika Volume 8, Nomor 2, Mei 2019 Copyright $\odot$ 2019Mosharafa: Jurnal Pendidikan Matematika 
menggunakan kalimat sendiri dan menggunakan simbol yang cocok disertai dengan alasan yang logis.

Duffin dan Simpson (Kesumawati, 2008) menyatakan bahwa pemahaman konsep yang dimaksud adalah siswa mampu mengucapkannya kembali konsep yang telah dikomunikasikan; menggunakan konnsep pada soal yang berbeda dan pemahaman konsep dapat memberikan pemahaman yang mendalam sehingga siswa bisa mencapai hasil yang maksimal.

Siswa dapat dikatakan memiliki kemampuan pemahaman yang baik jika siswa tersebut dapat mengkontruksi pemahamannya sendiri sebagai bagian dari proses belajar (Anderson \& Krathwohl, 2001). Berdasarkan pendapat tersebut terlihat bahwa pemahaman siswa dapat terlihat bahwa siswa memahami apa yang dia pahami dari hasil pemahamannya terhadap materi tersebut. Oleh karena itu, siswa dikatakan paham jika bisa menggunakan konsepsi yang dia dapat setelah proses pembelajaran yang dilaksanakan oleh guru di kelas (Nuraeni \& Afriansyah, 2016).

School Mathematics Study Group (Nurhayati, 2010) merinci aspek pemahaman dalam perilaku: mengetahui konsep, hukum, prinsip, dan generalisasi matematika, mengubah dari satu bentuk matematika ke bentuk matematika yang lainnya dan mampu mengikuti suatu penjelasan. Berdasarkan pendapat tersebut terlihat bahwa pemahaman matematik dapat terlihat bahwa siswa mampu hafal terhadap konsep tersebut dan siswa dikatakan memiliki kemampuan pemahaman yaitu jika siswa tersebut dapat mengkorelasikan dengan konsep yang lainnya sehingga siswa terlihat menguasai konsep yang dimiliki dengan konsep yang lainnya.

Kemampuan pemahaman terdiri dari indikator menyatakan ulang sebuah konsep; mengklasifikasi objek-objek menurut sifat- sifat tertentu sesuai dengan konsep; memberikan contoh dan bukan contoh dari konsep; menyajikan konsep dalam berbagai bentuk representasi matematis; mengembangkan syarat perlu dan syarat cukup suatu konsep; menggunakan, memanfaatkan, memilih prosedur atau operasi tertentu; dan mengaplikasikan konsep untuk memecahkan masalah (Jihad \& Haris, 2009).

Adapun indikator dari pemahaman konsep yang dikemukakan oleh Sanjaya (2009) diantaranya: (1) mampu mengaplikasikan konsep yang sudah dimiliki; (2) siswa terbiasa dengan berbagai langkah yang berbada; (3) mampu mengklasifikasikan objek-objek berdasarkan dipenuhi atau tidaknya persyaratan yang membentuk konsep tersebut; (4) dapat memberikan penguatan terhadap contoh yang didapatkan dari memahami; (5) mampu menerapkan konsep secara algoritma; dan (6) siswa mampu mengembangkan konsep yang telah dia miliki.

Berdasarkan pengamatan langsung dilapangan, pada kenyataannya banyak siswa yang masih kesulitan dalam 
memahami konsep matematika. Mereka masih banyak melakukan kekeliruan dalam memahami materi ajar setelah dilaksanakan pembelajaran kesulitan tersebut terlihat bahwa siswa kurang mampu mengaplikasikan konsep yang telah dimilikinya.

Lingkaran merupakan materi yang diberikan di kelas VIII. Soal pada materi ini sangat bervariasi sehingga guru dituntut untuk melatih siswa dalam menjawab soal yang berbentuk cerita (Mangelep, 2017).

Faktanya berdasarkan data nilai ulangan yang didapat dari guru mata pelajaran matematika pada materi lingkaran Tahun Pelajaran 2013/2014 diketahui bahwa dari 6 kelas siswa itu nilai yang didapat masih dibawah KKM dari siswa yang ada baru 40\% siswa yang mencapai KKM. Siswa mengalami kesulitan diantaranya: (1) kesulitan memahami konsep pada unsur-unsur lingkaran, dan (2) kesulitan ketika harus menerapkan konsep pada soal yang diberikan khususnya soal-soal yang berhubungan dengan kehidupan sehari hari. Peneliti meyakini karena materi lingkaran menjadi salah satu materi yang menjadi masalah dalam pembelajaran matematika khusunya di kelas VIII.

Jika siswa masih mengalami kesulitan dari hal-hal dasar tentang materi lingkaran, artinya siswa tersebut masih belum memahami tentang konsep dari lingkaran tersebut. Siswa dinyatakan memiliki kemampuan pemahaman matematis yang baik jika soal pada setiap indikator dapat terjawab dengan baik.
Hal ini dikarenakan jika seluruh indikator terpenuhi maka pemahaman konsep siswa dapat dilihat dan dinyatakan secara utuh. Salah satu contohnya dalam menyebutkan unsur-unsur dari suatu lingkaran, dikatakan memehami konsep jika siswa tersebut mampu menyebutkan dengan tepat unsur-unsur atau bagianbagian dari suatu lingkaran. Tujuan dari penelitian ini adalah untuk mendeskripsikan kemampuan pemahaman konsep siswa pada materi lingkaran.

\section{Metode}

Metode penelitian yang digunakan adalah kualitatif deskriptif. Bentuk penelitian deskriptif yang digunakan adalah penelitian kasus. Analisis deskriptif dimungkinkan untuk membahas secara mendalam mengenai kemampuan pemahaman matematik siswa yang menjadi pusat dari penelitian ini. Sehinga melalui penelitian deskriptif ini peneliti dapat mendeskripsikan jawaban siswa terhadap soal pemahaman matematik yang diberikan.

Siswa kelas VIII F SMPN 3 Karawang terpilih sebagai kelas untuk subjek penelitian. Subjek penelitian yang dipilih adalah siswa kelas VIII F SMPN 3 Karawang Barat Siswa dipilih berdasarkan random dari kelas yang ada kemudian kelas VIII F diambil sebanyak tiga orang.

Tes tulis merupakan teknik pengumpulan data. Tes sudah divalidasi terlebih dahulu oleh tim dosen pedidikan 300 
matematika UNSIKA dan guru matematika SMP sebanyak dua orang guru.

Hasil tes diolah terlebih dahulu dan digunakan untuk menentukan tingkatan siswa. Tes pemahaman matematis siswa yang terpilih menjadi pembahasan dalam penelitian ini.

Menurut Arikunto (2010) siswa dikategorikan dapat ditentukan berdasakan mean dan standar deviasi. Siswa yang berada di kategori tinggi yaitu siswa yang memperoleh nilai lebih dari nilai rata-rata yang dijumlahkan dengan standar deviasi; Siswa yang berada pada kategori sedang yaitu siswa yang memperoleh nilai diantara tinggi dan rendah; sedangkan siswa yang berada pada kategori rendahnya itu siswa yang memperoleh nilai kurang dari selisih nilai rata-rata dengan standar deviasi (lihat tabel 1).

\section{Hasil dan Pembahasan}

Hasil penelitian ini merupakan nilai yang diperoleh oleh siswa pada tes kemampuan pemahaman konsep dalam menyelesaikan soal-soal yang berhubungan dengan materi lingkaran (lihat tabel 2).

Tabel 2 menunjukan nilai siswa pada tes

Tabel 1.

Interval Kategori Pemahaman Konsep Matematis

\begin{tabular}{cc|}
\hline \multicolumn{1}{|l}{ Interval } & Kriteria \\
\hline$x>(\bar{x}+S D)$ & Tinggi \\
\hline$(\bar{x}-S D) \leq x \leq(\bar{x}+S D)$ & Sedang \\
\hline$(\bar{x}-S D)<x$ & Rendah \\
\hline
\end{tabular}

kemampuan pemahaman konsep matematis yang berjumlah 5 soal. Nilai tertinggi diperoleh dengan skor 17 dimana skor idealnya adalah dengan skor 25, dan nilai terendah berada pada skor 4. Jika ditelaah dari setiap indikator berdasarkan no soal, masih banyak siswa yang bisa dikatakan kurang dalam pemahaman konsep matematisnya. Berdasarkan hasil yang diperoleh tidak ada yang mencapai nilai maksimal atau berada di skor ideal. Dengan demikian dapat dikatakan bahwa pemahaman konsep matematis siswa dalam menyeesaikan soal-soal lingkaran masih rendah.

Kemudian skor rata-rata yang diperoleh adalah 10,06 dengan standar deviasi adalah 2,99. Melihat skor tersebut bahwa skor rata-rata masih jauh dari skor ideal yang ditentukan yaitu 25. Data diperoleh dari jawaban siswa kemudian dianalisis berdasarkan skor yang didapat siswa tersebut (lihat tabel 3).

Tabel 3 menunjukan persentase Tabel 2.

Hasil tes Pemahaman Konsep Matematis Siswa

\begin{tabular}{ccccc}
\hline $\begin{array}{c}\text { Jumlah } \\
\text { siswa }\end{array}$ & $\begin{array}{c}\text { Nilai } \\
\text { Maximum }\end{array}$ & $\begin{array}{c}\text { Nilai } \\
\text { Minimum }\end{array}$ & $\begin{array}{c}\text { Rata- } \\
\text { rata }\end{array}$ & SD \\
\hline 48 & 17 & 4 & 10,06 & 2,99 \\
siswa & & & &
\end{tabular}

Tabel 3.

Tingkat Pemahaman Konsep Matematis Siswa Kategori Kriteria Jumlah Persentase

\begin{tabular}{|cccc|}
\multicolumn{1}{c}{ Nilai } & siswa \\
\hline Tinggi & $>13,05$ & 6 & 12,5 \\
\hline Sedang & $\begin{array}{c}7,07 \\
\\
\end{array}$ & 36 & 75 \\
& $\leq$ Nilai & & \\
& $\leq 13,05$ & & \\
\hline Rendah & $<7,07$ & 6 & 12,5
\end{tabular}


kemampuan pemahaman konsep matematis siswa dalam menyelesaikan soal-soal materi lingkaran. Pada kriteria tinggi terletak pada nilai lebih dari 13,05, dan terdapat 6 siswa yang berada di kriteria tinggi yaitu sebesar 12,5\%. Pada kriteria sedang terletak pada nilai antara 7,05 sampai dengan nilai 13,05 , dan terdapat 36 siswa yang berada pada kriteria sedang yaitu sebesar $75 \%$. Pada kriteria rendah terletak pada nilai kurang dari 7,07, dan terdapat 6 siswa yang berada pada kriteria rendah yaitu sebesar $12,5 \%$.

Data hasil tes kemampuan pemahaman konsep matematis siswa kelas VIII didapat berdasarkan hasil yang diperoleh siswa setelah mengerjakan tes tertulis dalam bentuk uraian. Lembar jawaban siswa merupakan data yang didapat oleh siswa. Gambar 1 adalah soal tes kemampuan pemahaman konsep matematis siswa dan cara menyelesaikannya.

Melalui soal ini peneliti bisa mendapatkan gambaran mengenai kemampuan pemahaman matematik yang sifatnya pada pemahaman konsep yaitu mengetahui bagian bagian lingkaran.

Cara menyelesaikan soal no 1 adalah siswa harus paham tentang konsep tentang lingkaran dan unsur-unsur yang ada pada lingkaran.

Berdasarkan jawaban dari salah satu siswa, siswa tersebut tidak mengerti unsur-unsur lingkaran, artinya pemahaman konsepnya tentang unsurunsur lingkaran sangat rendah dilihat dari jawaban siswa. Indikator mengulang 302 sebuah konsep tidak nampak pada siswa ini (lihat gambar 1).

Gambar 2 merupakan soal tes kemampuan pemahaman konsep matematis yang kedua. Jawaban soal nomor 2 yang dikerjakan salah satu siswa adalah untuk mencari keliling dan jarak tempuh, siswa tidak bisa mengerjakan dikarenakan kemampuan menghitung siswa dalam hal operasi bilangan bulat menggunakan bilangan desimal masih rendah.

Pada soal nomor 3, siswa tidak dapat menerapkan hubungan antar konsep dan prosedur, dan melakukan operasi hitung

Soal 1: Dari gambar di bawah ini sebutkan dan berikan penjelasan yang termasuk: a) Jari-jari; b) Diameter; c) Pusat Lingkaran; d) Tali Busur; e) Busur; f) Apotema; g) Juring; h) Tembereng.
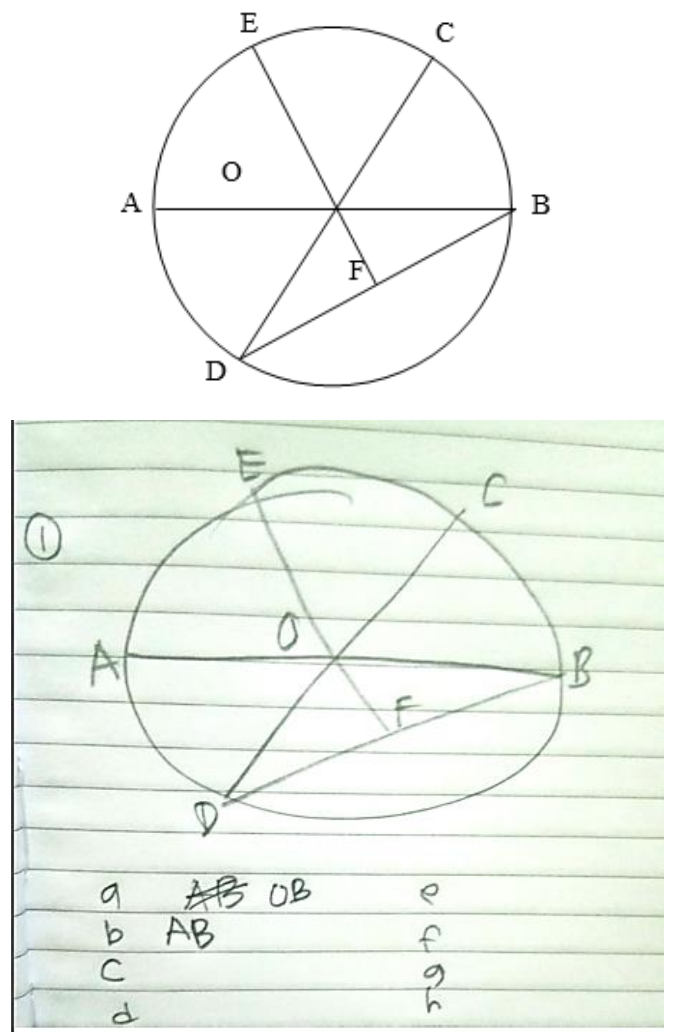

Gambar 1. Soal dan Jawaban Nomor 1

Mosharafa: Iumal Pendidikan Matematika Volume 8, Nomor 2, Mei 2019 Copyright $\odot$ 2019Mosharafa: Jurnal Pendidikan Matematika 
sederhana, mengklasifikasikan objek-objek pun tidak dapat siswa lakukan. Untuk mencari harga tanah salah satunya harus mencari dulu luas tanahnya (lihat gambar 3).

Pada soal nomor 4 siswa diharapkan dengan paham tentang konsep keliling lingkaran dapat menghitung panjang lintasan, tetapi masih ada siswa yang merasa kesulitan mengerjakannya. Siswa tidak dapat menerapkan konsep secara algoritma, harusnya mencari keliling (lihat gambar 4).

Jawaban siswa yang ditampilkan, siswa belum bisa menggambar dengan betul apa yang tertera pada soal, dengan begitu konsep yang seharusnya tidak dapat terpenuhi (lihat gambar 5). Siswa tidak dapat menyajikan situasi matematika ke dalam berbagai cara, tidak dapat mengembangkan konsep yang telah dipelajari. Dengan gambar yang tidak

Soal 2: Doni pergi ke toko buku naik sepeda, jika panjang jari-jari rodanya adalah $70 \mathrm{~cm}$. Ternyata sebuah roda sepedanya berputar 1000 kali untuk sampai ke toko buku. a) Tentukan keliling roda itu? b) Hitunglah jarak yang ditempuh Doni?

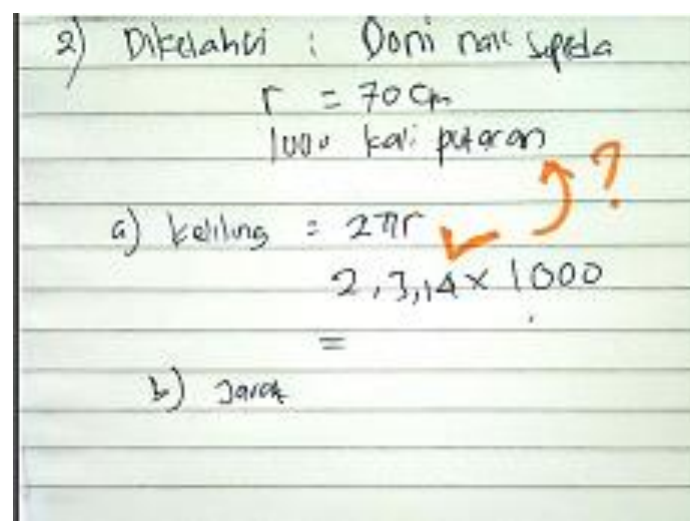

Gambar 2. Soal dan Jawaban Nomor 2 sempurna siswa kesulitan dalam mengungkapkan konsep yang dia miliki terhadap soalnya, yaitu bahwa itu bagian dari lingkaran dan itu bisa dikerjakan dengan menghitung seluruh bangun dikurangi yang tidak diarsir. Hasil tersebut sesuai dengan temuan Mangelep (2017) yang mengatasi kesulitan siswa tersebut dengan pendekatan software. Berdasarkan hasil wawancara juga dapat dilihat bahwa siswa masih merasa kesulitan mengenai konsep yang harus digunakan dalam menjawab soal lingkaran. Kesulitan ini dikarenakan kemampuan memahami

Soal 3: Sebuah taman berbentuk setengah lingkaran, jari-jari taman tersebut adalah $14 \mathrm{~m}$. Jika harga setiap $\mathrm{m}^{2}$ tanah adalah $\mathrm{Rp} 30.000,00$. Berapa luas dan biaya untuk membeli tanah tersebut?

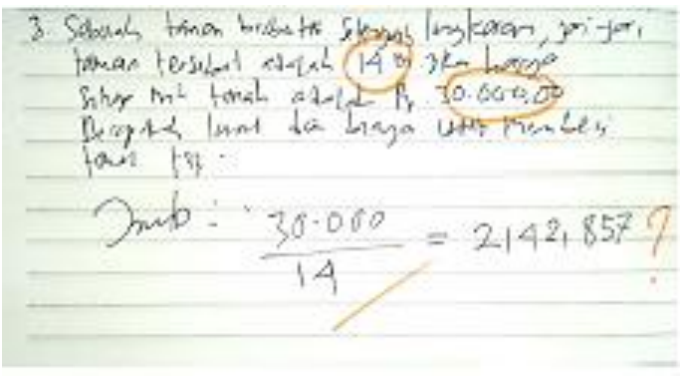

Gambar 3. Soal dan Jawaban Nomor 3

Soal 4: Panjang jari-jari sebuah roda motor adalah $30 \mathrm{~cm}$. Jika roda itu berputar 200 kali, hitunglah panjang lintasan roda tersebut!

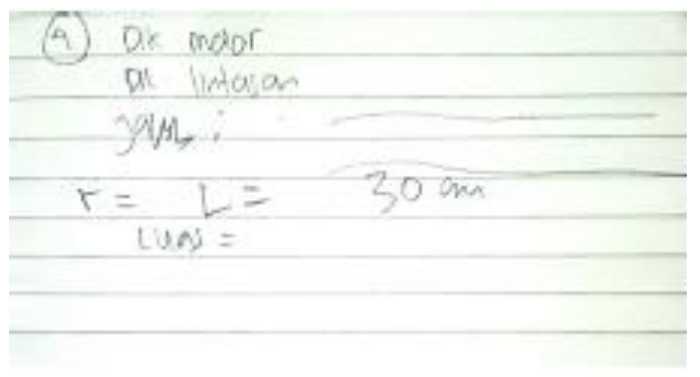

Gambar 4. Soal dan Jawaban Nomor 4 
materi yang masih perlu ditingkatkan (Dewi \& Minarti, 2018).

Berdasarkan hasil penelitian dapat disimpulkan kemampuan pemahaman konsep matematis siswa kelas VIII F di SMP Negeri 3 Karawang Barat Tahun Ajaran 2013/2014 yaitu kriteria baik 12,5 \% (6 siswa), kriteria sedang $75 \%$ (36 siswa) dan kriteria rendah $12,5 \%$ (6 5 siswa). Sedangkan rata-rata nilai kemampuan pemahaman konsep matematis siswa adalah 10,06, sejalan dengan penelitian Supriyatna \& Afriansyah (2018), termasuk dalam kriteria sedang. Dari hasil analisis konsep per indikator, sejalan dengan

Soal 5: Luas daerah yang diarsir pada gambar di bawah ini!

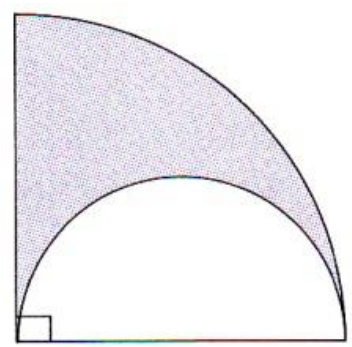

$28 \mathrm{~cm}$

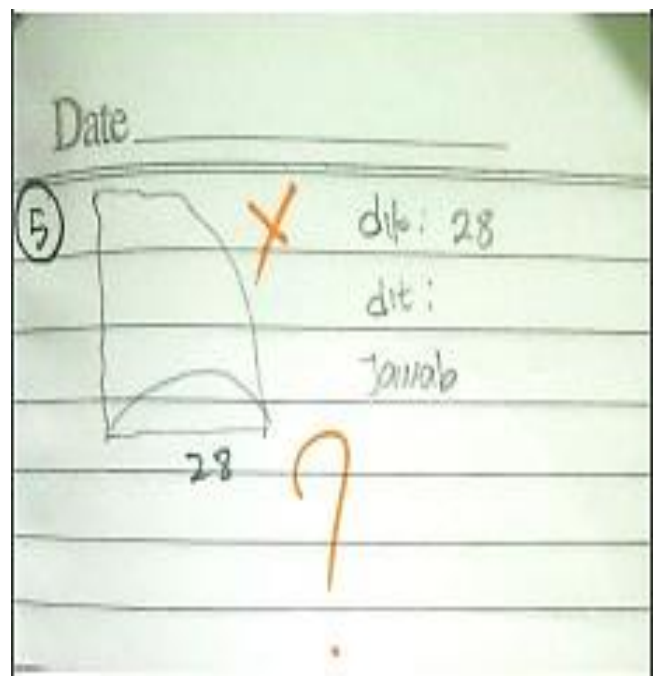

Gambar 5. Soal dan Jawaban Nomor 5 penelitian Mulyani, Indah, dan Satria (2018), diketahui siswa sangat kurang pada indikator menerapkan hubungan antar konsep dan prosedur, kemudian dalam menerapkan konsep secara algoritma (langkah-langkahnya).

\section{Penutup}

Dalam penelitian ini, terdapat banyak siswa yang masih memiliki pemahaman konsep yang kurang. Pembelajaran materi lingkaran sebaiknya lebih memfokuskan pada pemahaman konseptual, karena pemahaman konsep merupakan hal yang penting dan mendasar untuk pembelajaran berikutnya. Kebiasaan siswa dalam berlatih dalam menjawab soal dapat berdampak positif, yaitu siswa mampu memahami secara mendalam konsep yang sedang diajarkan oleh gurunya.

\section{Daftar Pustaka}

Afriansyah, E. A. (2017). Problem Posing sebagai Kemampuan Matematis. Mosharafa: Jurnal Pendidikan Matematika, 6(1), 163-180.

Alexandra, G., \& Ratu, N. (2018). Profil Kemampuan Berpikir Kritis Matematis Siswa SMP dengan Graded Response Models. Mosharafa: Jurnal Pendidikan Matematika, 7(1), 103-112.

Anderson, L. W., \& Krathwohl, D. R. (2001). A Taxonomy for Learning Teaching and Assessing. New York: Longman. 
Arikunto, S. (2010). Prosedur Penelitian Suatu Pendekatan dan Praktik. Jakarta: PT. RinekaCipta.

Dewi, S. J., \& Minarti, E. D. (2018). Hubungan antara Self-Confidence terhadap Matematika dengan Kemampuan Pemecahan Masalah Matematik Siswa pada Materi Lingkaran. Mosharafa: Jurnal Pendidikan Matematika, 7(2), 189198.

Ekafitria, E. (2012). Analisis Pemahaman Mahasiswa terhadap Konsep Limit Di Satu Titik. Tesis Tidak Diterbitkan. Makassar: Program Pascasarjana Universitas Negeri Makassar.

Fitriani, S., \& Yarmayani, A. (2018). Pengembangan Rubrik Berpikir Kreatif Siswa Menengah Atas dalam Menyelesaikan Masalah Matematika. Mosharafa: Jurnal Pendidikan Matematika, 7(1), 33-38.

Jihad, A., \& Haris, A. (2009). Evaluasi Pembelajaran. Yogyakarta: Multi Press.

Kesumawati, N. (2008). Pemahaman Konsep Matematik dalam Pembelajaran Matematika. (http:// http://eprints.uny.ac.id/6928/1/P18\%20Pendidikan\%28Nila\%20K\%29.p df).

Mangelep, N. O. (2017). Pengembangan Perangkat Pembelajaran Matematika pada Pokok Bahasan Lingkaran Menggunakan Pendekatan PMRI dan Aplikasi GEOGEBRA. Mosharafa: Jurnal Pendidikan Matematika, 6(2), 193-200.

Mosharafa: Jurnal Pendidikan Matematika Volume 8, Nomor 2, Mei 2019 Copyright @ 2019Mosharafa: Jurnal Pendidikan Matematika
Mulyani, A., Indah, E. K. N., \& Satria, A. P. (2018). Analisis Kemampuan Pemahaman Matematis Siswa SMP pada Materi Bentuk Aljabar. Mosharafa: Jurnal Pendidikan Matematika, 7(2), 251-262.

Muna, D. N., \& Afriansyah, E. A. (2016). Peningkatan Kemampuan Pemahaman Matematis Siswa melalui Pembelajaran Kooperatif Teknik Kancing Gemerencing dan Number Head Together. Mosharafa: Jurnal Pendidikan Matematika, 5(2), 169176.

Nuraeni, Y., \& Afriansyah, E. A. (2016). Peningkatan Kemampuan Pemahaman Matematis Siswa Melalui Pembelajaran Kooperatif Tipe Rotating Trio Exchange. Jurnal Inovasi Pendidikan Dasar, 1(2), 85-94.

Nurhayati, Y. (2010). Upaya Meningkatkan Kemampuan

Pemahaman Matematika Siswa Melalui Pembelajaran Kooperatif Tipe STAD. Skripsi STKIP Garut: Tidak Diterbitkan.

Sanjaya, W. (2009). Strategi Pembelajaran Berorientasi Standar Proses

Pendidikan. Jakarta: Prenada.

Suherman, E. (2001). Strateg iPembelajaran Matematika Kontemporer. Bandung: JICA UPI.

Sundayana, R. (2013). Media Pembelajaran Matematika. Bandung. Alfabeta.

Supriatna, R., \& Afriansyah, E. A. (2018). Kemampuan Pemahaman Matematis Peserta Didik melalui Cooperative Learning Tipe Pair Checks VS Problem 
Based Learning. Jurnal Pendidikan

Matematika Indonesia, 3(1), 1-6.

Van de Walle, J., A. (2008). Matematika

Sekolah Dasar dan Menengah.

Jakarta: Erlangga.

Zulkardi. (2003). Pendidikan Matematika

Republik Indonesia. http://pmri.or.id/, diakses tanggal 5 Agustus 2014.

\section{Riwayat Hidup Penulis}

\section{Attin Warmi M. Pd.}

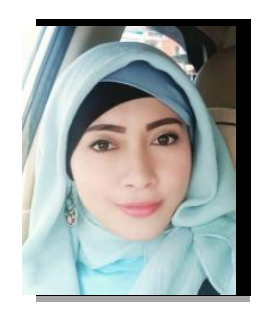

Lahir di Garut pada tanggal 28

Juni 1980. Mengajar di program studi Pendidikan Matematika Universitas Singaperbangsa Karawang. 